\title{
The Status and Role of Cooperatives and Cooperative Bank of Oromia in the Socio-Economic Development in Ethiopia
}

\author{
Desalegn Fekadu Etefa \\ Ambo University: College of Business and Economics, Department of Cooperative Studies
}

\begin{abstract}
Cooperative is a useful instrument to alleviate the socio-economic problems of the people in many developing countries including Ethiopia. Cooperation among people has existed since time immemorial. However, formal cooperatives began in Ethiopia in 1960. Following this, with the initiative of the government to encourage financial institutions, Cooperative Bank of Oromia was emerged in 2004. Since its establishment, Cooperative Bank of Oromia played its share to solve the bottleneck of institutions and individuals in delivering both financial and non-financial services to the unbanked and under banked communities as well as to sustain the cooperative institutions. The objective of this review article is to show the status and role of cooperatives and Cooperative Bank of Oromia in the socio-economic development in Ethiopia. Intensive conceptual and empirical literature reviews were made in the areas of cooperative development, cooperative policy and regulatory framework documents, annual reports of Cooperative Bank of Oromia and the Federal Cooperative Agency's report. The study indicated that the number of primary cooperatives has increased from 7,366 in 1991 to 82,089 at the beginning of 2019 showing $1,014 \%$ rate of growth. The number of members increased from 4.5million to 18 million during the same period demonstrating growth rate of $297 \%$. Their capital was increased from half billion to 20.5 billion birr during the stated periods. Likewise, Cooperative Bank of Oromia has shown dramatic progress. Its capital is increased from 300 million to more than 5 billion; the numbers of branches increased from 7 to 420 , number of employees are 8,163 . The review confirmed that the bank is contributing multi-directional socio-economic development in the country. It is obvious that if it continues in this manner, the bank will be one of the leading banking industries in the country.
\end{abstract}

Keywords: Cooperatives, Cooperative Bank of Oromia, Role, Status, Socio-Economic Contribution

DOI: $10.7176 / \mathrm{EJBM} / 13-7-02$

Publication date: April $30^{\text {th }} 2021$

\section{Introduction}

In the contemporary period, poverty is abolishing the lives of billions of the people around the world. As a result, many people sense incapable to change their lives. In this hardship situation, cooperatives emanated to be a strong, active, and feasible economic opportunity to alleviate poverty. The concept of human cooperation is not new; it existed even before the formation of modern cooperation. To overcome their immediate problems and to share their feelings, human beings traditionally work together in day to day life. As it is stated by Gary (1993), cooperative is an association of persons who have voluntarily joined together to achieve a common goal. They finance and operate the business for their mutual benefit. This implies they are created on the leading idea that by working together, a group of people can achieve an objective that would be unattainable if acting alone (Ruhul \& Mahin, 2014; Desalegn, 2019).

Evidence from various sources reveals that cooperatives are contributing to the country's economic and social development. For instance, report of International Cooperative Alliance (ICA) (2019) stated that about one billion people are involved in cooperatives, either as members or, as employees or both. The same source further indicated that nearly 280 million people get employment opportunities from cooperatives at global level. The livelihoods of almost half of the world's population are safeguarded by cooperative enterprises. This is particularly true in the rural areas where it provides an important potential for income generation and equity for the dwellers.

In order that cooperatives play their role, government's aid is highly required. Government supports cooperatives in creating enabling environment. These include putting in place sound economic policy, technical, legal and administrative support to sector development, providing regulatory frameworks and transparent system; all of which together will create an environment conducive to sector development (United Nations Framework Convention on Climate Change (UNFCCC), 2014).

As modern business structure, cooperatives originated in Britain by Robert Owen in 1844 and it was introduced to Ethiopia by 1960 during imperial Hailesillasie regime. Successive governments, starting from the Imperial period to the present government, gave due attention to the role of coops and made deliberate effort to promote the same. However, the principles and approaches followed were obviously different, reflecting the political thinking and ideology of the regimes.

As indicated in the work of Kifle (2015a), Ethiopian People's Revolutionary Democratic Front (EPRDF) provided Proclamation No. 147/1998 and 402/2004, which served as a legal framework. This declaration 
combined universally accepted principles of cooperatives. As a result of these; many cooperatives have been established in new forms in Ethiopia since 1998 following the initiatives taken by the government, but suffered from adequate financial support which is convenient to the unique nature of the sector.

Ethiopia has continued to become one of the fast-growing economies in Africa. The country highly emphasized on the foreign direct investment (FDI), export-oriented industrialization and private sector development. It has recorded an economic growth of 8.4 percent in the fiscal year 2019/20 (World-Fact Book, 2020). In this rapidly growing economy, the banking sector dominates the financial sector of Ethiopia in terms of value, market share and services offered to the public.

Banking system is vital for the development of every nation's economy. It may not be an exaggeration to assert that without the evolution of commercial banks in the $18^{\text {th }}$ and $19^{\text {th }}$ centuries, industrial revolution would not have occurred in Europe. It is equally true that without the development of sound commercial and Cooperative banking, underdeveloped and developing countries cannot hope to join the group of advanced countries. Strong banking system enhances business activities and eventually promotes the national economy (Nakkiran, 2002).

Banks contribute by inspiring confidences in people, making them willing to save their surplus money with them instead of buying gold and investing on old traditional valueless things. Banks also provide not only funds, the basic fuel for economic growth but also canalize into productive avenues (Gobena, 2011). A developing economy requires continuous process of investment and this intern requires aggregate rise in money-cash, credit supply. Banks divert and employ funds in such avenues which are aimed to develop the country's economy and add to the national wealth. They also create credit and add to the supply of money. Credit provides more funds to entrepreneurs that lead to more investment and more production both for agriculture and industry. High production leads to self-sufficiency hence increase of export items that gains foreign earnings for the country, which is leading to development.

Contrary to this fact, Ethiopia's financial sector remains closed to foreigners, and is much less developed than its neighbors. The year before 1992 (during the Derg period), in Ethiopia, the financial sector was highly repressed; characterized by restricted entry, constrained banks' role on interest rates, credit limits and others. Moreover, the then existing government owned banks were under pressure by regulation from the central government as the country was governed by command economy. This institutional framework led to a situation of virtually no competition in the banking sector, with total concentration of banking activities in government owned banks. In fact, the government stance was to minimize the extent of competition between the commercial banks and existing specialized banks (Tesfay, 2016).

As a result, the country has no capital market so far and very limited informal investing in shares of private companies. However, after the change of the government, a series of financial sector reforms has been introduced since 1994 including the financial sector which enabled the banks to set lending interest rate by their own. Moreover, the ban on entry of private banks, owned by domestic businessmen was abandoned. As the government is committed to alleviating poverty, private sector development is seen to be the main option through integrating Ethiopia into the global economy (Gobena, 2011). Consequently, nineteen commercial banks (16 private and 3 government banks) are operating in Ethiopia at present though these state owned banks continue to dominate the market in terms of capital, deposits and assets.

In this situation, Cooperative Bank of Oromia S.C has emerged as one of the private commercial bank in the sector, which has been actively moving to boost its market share and contribute to the strong support to the cooperative sectors and to the economic development of the country at large. Following the Monetary and Banking Proclamation of 1994, several private banks have been opened in Ethiopia (Alemayehu, 2001). Cooperative Bank of Oromia as one of the emergent bank was established in 2004. Therefore it is necessary to show the status and the role the bank plays its share in the socio-economic development of the country so as to motivate the founders of the bank and also all its employees to boost the current performance.

\section{Objective of the Review}

The main objective of the review is to show the role of cooperatives and Cooperative Bank of Oromia (Coopbank) in the socio-economic development of the country.

\section{Methods}

The methodological approach adopted in this review is "best evidence review" whose focus is targeted towards combining various systematic methods of study-selection and result exploration. The data were collected from various secondary sources such as, policy and regulatory framework documents, past study reports and cooperatives periodic activity reports, Federal Cooperative Proclamation No 147/1998 and Cooperative Societies (Amendment) Proclamation No. 402/2004. The most prominent secondary data were obtained from the Federal Cooperative Agency of the country and annual report of Cooperative Bank of Oromia. Moreover, based on their relevance, over very recent 30 related published journal articles, some newspaper articles, magazine articles and 
books were referred and used as a background to analyze and synthesize the existing conditions regarding the title in the country. Depending on these, data were examined and interpretations were done to show the status and the role of cooperative societies and Cooperative Bank of Oromia. Basing the principles and values of cooperatives, the practical situation in the sectors is examined and the problems encountering were identified. Eventually, the proposed interventions and strategies to be adopted are indicated.

\section{Historical Development of Cooperatives and Cooperative Bank of Oromia 4.1 Footing Ground of the overall Cooperatives in Ethiopia}

Modern cooperatives movement introduced to Ethiopia in 1960. Of the ruling body existed in the country, main emphasis in this article review is given to the three regimes that have contributed to the cooperatives' development in Ethiopia, viz., Hailesillasie (1916-1974) Derge/military (1974-1991) and EPRDF regime \& PP (from 1991 onwards).

During the imperial Hailesillasie regime, cooperatives have got recognition by Decree No. 44 of 1960 (FCA, 2005 cited in Bezabih, 2009). This decree had its own limitations due to this; another new Cooperative Society Proclamation No. 241/1966 was to come to operative with concern of previous Decree's short comings. This enabled the cooperative society to realize their objectives. In its Five Year Development Plan, the Imperial regime envisioned an important role for coops in transforming smallholding agriculture. Thus, the Farmer Workers Cooperative Decree No. 44 was provided the first legal framework, which was later replaced by the Cooperative Societies Proclamation No. 241/1966. This was relatively comprehensive and contained most of the essential contents of the legal framework. However, success was limited during the period due to several limitations with it (Mojo et al., 2015). It was also failed to be in line with the international cooperative principles and they were exclusive to farmers with larger farm sizes (Abate et al., 2014). Hence, they failed to survive in the succeeding regime.

In the reign of military regime, proclamation 1975 was ratified. This proclamation set condition for the nationalization of rural land and extra houses in urban areas on its article 10. Simultaneously, this decree provided for the creation of marketing and credit cooperatives by peasant association. After the overthrow of Emperor, Cooperative Societies proclamation No. 138 issued in 1978. The intention of the military regime was to use coops as a key instrument to build a socialist economy. Thus, it pursued the cooperatives agenda more aggressively. The cooperatives were not autonomous organizations, but had purely political character. The approach followed combined force with extensive support including priority access to resources, goods and services. The number of coops and membership sizes were relatively large; but it was not viewed as a particular success for a number of causes. Due to this reason, following the downfall of Derge regime, most of them disappeared rapidly. The number of primary cooperatives reached 10, 524 having 4,529,259 members started to decline following the decease of the Derge regime. The reason for their immediate disappearance is, by then, their property particularly cash was in the hands of the government structures (political party the then Ethiopian Socialist Party). During this period, cooperatives were made state machinery in the socialist economy. The farmer's lands were grabbed by farmers' producers' cooperative societies in almost all over the country and collective farming was practiced. According to McCarthy (2001), it served as a vehicle to eliminate internal conflicts and also characterized by corruption and mismanagement. All farmers' resources were also taken over by these collective framings. After the fall of the Derg regime, as cooperatives were considered to be the state machinery, they were hated together with the fallen regime. As a result, with the collapse of this structure, the properties of the coop societies were lost. Consequently, there was no distribution of assets between members. This created a lasting suspicion and distrust of cooperatives even until today (Kenichi Ohno, 2009).

Another new era appeared in the history of cooperatives with the emergence of new government in 1991. This new government when he came to the power, economic liberalization policies were first implemented in 1991. These policies have been effective in releasing the economy from rigid state control, but also mean that Ethiopian people have become exposed to the hazards of both domestic and international free market competition (Kodama, 2007). That means; they were facing challenges emanating from globalization, where the issue of competition and market pressure emerges (Cemal, 2019). Such issues are still affecting cooperatives of developing countries in general and Ethiopia in particular.

The Ethiopia People's Revolutionary Democratic Front (EPRDF) provided a new legal framework, which is entitled Proclamation No. 147/1998 and 402/2004 to promote cooperatives from 1991. The past experience, particularly the bad habit inherited in cooperatives during the Derg regime was highly hindering the development of cooperatives. In this regard, evidence shows that the numbers of primary cooperatives existing in Derge regime declined to 7,366 in 1991. Thus, EPRDF had taken some years to build new mind-set up and to change the attitude of the community towards cooperatives (Holmberg, 2011). In connection to this, some "cooperative activists" and organizers assisted the government to reconsider the cooperatives positively. As stated by Holmberg (2011), ILO also played crucial roles in the renaissance of the cooperatives in Ethiopia, by organizing study tours for cooperative activists and leaders to strengthen their empathetic and leadership skills through 
sharing the experiences of the neighboring countries. Due to this, the government's opinion of cooperatives had rehabilitated and policymakers generally accepted the meanings and principles of cooperatives given by the ICA in 1995 (FCA, 2014). Consequently, these determinations led to the establishment of cooperative legislations that opened up a room for the flourishing of modern cooperatives in Ethiopia.

Succeeding this, new Legal Framework that guides the development of cooperatives enacted in the country. This legal framework is known as Proclamation No. 85/1994, which was introduced to serve only agricultural cooperatives, with an aim to realize improved living situations to its members (Adugna, 2013). This proclamation states that "the government sets convenient conditions for the peasants living in rural areas to be organized freely and willingly to jointly solve their economic and social problems through pulling their resources." Contrary to the past two regimes, the EPRDF government opened a legal space to organize cooperatives voluntarily, democratically and within a market setting. Nevertheless this proclamation facilitated to rearrange farmers on a voluntary basis to establish new cooperatives or to reorganize and strengthen the old ones, the organizers had a hard time to change peoples' attitude towards cooperatives due to the bad image of the cooperatives of the Derg regime (Holmberg, 2011). Some measures taken shifted the minds of the members among which; sharing dividends after a year that in some way helped to encourage the use of the cooperatives. Alike the past two regimes, the first cooperative society proclamation (No. 85/1994) of EPRDF was also only targeting the agricultural cooperatives and lacks sufficient details. As a result, the government enacted the second proclamation (No. 147/1998) in 1998. This proclamation outlined the layers of organizational structure of the cooperatives into primary cooperatives, unions, federations, and cooperative leagues that can foster broader growth of the movement (Kodama, 2007). The proclamation also specified related organs of the cooperatives that include members, a general assembly, a special resolution, and a management committee with clear roles and responsibilities.

As a matter of this new proclamation and amendment, cooperatives principle became inclusive and universally accepted among societies. This has led to the appearance of some improvements in cooperative sectors, which in turn brought changes in the cooperative societies of the country. However, revision with this proclamation was undertaken with delay after 2016, which is 18 years later. There is also limitation to implement this proclamation among all parts.

For instance, cooperative societies shall aim to solve social and economic problems by harmonizing their knowledge, wealth, and labor as stated by proclamation No.47/1998. The government of Ethiopia established cooperative societies to bring all types of cooperative under one umbrella by proclamation No. 147/ 1998 . Besides, the majority of the cooperatives have been initiated by the government, which shows its strong interest in cooperative movement, including cooperative governance which by itself raises the questions of cooperative independence.

Agricultural cooperatives were established and managed by government staffs, and membership was made compulsory. As a result, farmers failed to see the value and this perception was created in the cooperative institutions. Thus, cooperatives were without members' control, and finally the cooperatives were captured by a small elite and middle class bureaucracy. They were also heavily dependent on government subsidies, instead of independence and self-reliant organizations in most developing countries (Mojo, 2017). Therefore, government interference is prevailing in the contemporary cooperatives being one of the cooperatives management issues in Ethiopia.

The government of Ethiopia has taken sympathetic actions in the history of cooperative movement after the year 1996. The measures include, organizing and reorganizing different types of agricultural cooperatives and establishing Cooperative Promotion Bureaus in regional states. At the Federal structure, the government has been established the cooperative promotion desk under the Prime Minister office. The Federal Cooperative Commission (currently Federal Cooperative Agency), which is the highest government structure for cooperative promotion in the country was established in 2002 based on proclamation No. 274 / 2002. This Proclamation suits to the currently universally accepted ICA's cooperative principles and the ILO's Promotion of cooperative Recommendation 2002 (No. 193). This infers the basic principles and values of the present day Ethiopian cooperatives are adopted from ICA. Nevertheless, the unanswerable issue is about the degree of implementation of the principles and realities on the ground among the non-educated members in particular. Moreover, to correct the short comings in the proclamation 147/1998; regulation number 106/2002 and amendment 402/2004 became an important instrumental document in the cooperative movement of the country (Addissie \& Dagnachew, 2009). In general, since the commencement of modern cooperatives, Ethiopia has decreed four main new proclamations and an amendment act. These are Directive No.44/1960, Proclamation No.241/1966; Proclamation No.138/1978, Proclamation No. 85/1995, Proclamation No. 147/1998, and Amendment act No. 402/2004 (Bezabih, 2009). All these acts demonstrate that the federal and regional governments have recognized the contribution of cooperatives to economic and social development, food security and poverty reduction in Ethiopia. 


\subsection{Historical overview of Cooperative Bank of Oromia (Coopbank)}

The history of co-operative banks has been traced back to the financial exclusion faced by many communities in $19^{\text {th }}$ century. With the industrial revolution, the emerging financial services sector was primarily focused on wealthy individuals and large enterprises in urban areas. The rural population, particularly farmers, small businesses and the communities they supported, were excluded from financial services. Thus, co-operative banks were originally set up to correct this market failure and to overcome the associated problems of asymmetric information in favor of borrowers. Beginning in Germany, the co-operative banking concept gradually spread to the rest of the continent and to the Nordic countries (Nakkiran, 2002; Cooperative Bank of Oromia, 2019). In respect of Ethiopia, the country has very low financial service coverage as mainstream financial institutions are heavily tilted towards the urban centers with good physical infrastructure, leaving the rural areas underserved. Traditionally, 'Equbs' and 'Idirs' are informal institutions that are deeply ingrained in the life communities and have also been serving financial needs of the society (FCA, 2012). Reluctance and low capacity of the financial institutions in the country to serve rural community, a demand-supply gap prevailed in financial market especially in rural areas, coupled with farmers awareness to be organized in to cooperatives and the increasing need to finance cooperatives' called for establishment of a cooperative bank (Gobena, 2011). Furthermore, finance appeared to be the critical bottleneck to sustain the cooperative institutions and ultimately the farmers.

Due to this fact, change of policy is necessitated from a command to a market economy in Ethiopia. Thus, the government has taken steps since 1994 to liberalize the economy through the Structural Adjustment and Economic Recovery Programme. As part of this wider reform agenda and given the importance of banking sector in the economy, the government has undertaken a policy reform of financial sector to develop the sector and enable private domestic investors to be engaged in banking and finance industry. Consequently, the financial and Banking Proclamation No. 83/1994 together with the Licensing and management of Banking Business No. 84/1994 settled the legal basis for the private sector investment chance in the banking industry (Alemayehu, 2001). This has given the chance for the emergence of a new era of competitive atmosphere, the abolishment of the monopoly of the general public banks (Commercial Bank of Ethiopia, Business Bank and Development bank of Ethiopia) and institution of diverse personal banks within the country as well as Cooperative Bank of Oromia (Gobene, 2011; Cooperative Bank of Oromia, 2019).

It was all these glitches that initiated the inception and establishment of Cooperative Bank of Oromia. The founding father (proponent), Mr. Haile Gebre Lube brought the idea of founding the bank for he believed that the best way to fight poverty is through cooperation. Formally establishing a project office in 2002, the bank's formation was realized (CBO, 2019). The cooperative bank of Oromia is established by the cooperative movement to play its share in delivering financial services to the unbanked and under banked communities as well as to sustain the co-operative institutions. It has a unique operating model and value propositions for cooperatives, where $67 \%$ of its shareholdings being held by co-operative societies. It is also one of the largest banks in the Ethiopian banking industry, with huge retail branch networks in rural areas. As there are no legal provisions that allow establishment of a cooperative bank in the country, the bank was registered in accordance with article 304 of the commercial code of Ethiopia and was licensed by National Bank of Ethiopia as per proclamation No. 84/1994 that provides for licensing and supervision of banking businesses, with Registration No., IBB/008/2004. The bank is established with three hundred million Eth Birr issued share and paid up capital of 112 million. Currently the paid up capital of the bank reached more than five billion Eth. Birr (CBO, 2020).

The head quarter of Cooperative Bank of Oromia is located at Addis Ababa, which is the capital city of Oromia Regional State, Ethiopia and Africa Unity. Currently, it has 420 branches operating as a network in most commercial cities and towns of Oromia Regional State including the capital city, Addis Ababa. The bank has a broad ownership base and diversified ownership structure. The bank's major shareholders are primary cooperative societies, which is up to 67 percent with the aim to pool their scarce resources and alleviate the problems of working capital and to increase their bargaining power with the ultimate objectives of improving the living standards of their grass root members. The bank has four divisions: Business development and Marketing division, Finance division, Planning division and Credit (Loan appraisal) divisions. Within those divisions a lot of experts with reach experience and cooperative spirit are working (CBO, 2020).

Shareholders of CBO are: Cooperatives, Development Organizations, Board of Directors, Top Managers, Individuals/residents and Pvt. Ltd. Companies. In connection to the composition of shareholders, $73.57 \%$ is held by Cooperatives, among that 69.2 percent is primary cooperatives and about 4.4 percent is by Cooperative Unions. The remaining Birr 26.44 percent shares are held by non-cooperative members.

As of June 2020, the bank's account holders are about 6.25 Million, which makes the bank the prominent private bank. The number of employees of the bank as of 2020 is more than 8,163 . The bank has 420 branches, of which more than 80 percent are outside the capital city of the country where the industry average is still less than 60 percent; this indicates the bank's focus is to the grassroots level (rural area). According to the June 2020 report, Cooperative Bank of Oromia (Coop Bank of Oromia) has ETB 52.92 billion in assets, capitals account to ETB 5.11 billion, and ETB 45.52 billion in deposits, making the bank among the top three private banks in 
Ethiopia (CBO, 2020).

As far as the organizational structure of $\mathrm{CBO}$ is concerned, the top body of the Cooperative Bank of Oromia is the General Assembly (shareholders/owners of the bank) who has the basic right to decide the objectives, existence and operations of the bank. The General Assembly elects representatives, the Board of Directors, to whom all the powers to run the Bank are conferred upon. Board of directors employs the president of the Bank who is assigned to perform the functions relating to policy matters, implementation and supervision (CBO, 2019).

Ultimately, the Cooperative Bank of Oromia has joined the International Cooperative Alliance (ICA), an independent non-governmental organization representing co-operatives in the globe, which was founded in 1895 with the main objective to promote and strengthen co-operatives all over the world. Its members are national and international co-operative organizations in all sectors of activity, including agriculture, banking, credit and saving, industry, insurance, fishing, social housing, health, public services, consumer services and tourism. Furthermore, the alliance endeavors to encourage and defend the values and principles of the cooperative movement, stimulates mutually beneficial relations between its member organizations and favors the economy and social progress of people.

Becoming the member of the ICA will benefit the bank in many ways among which for global networking, learning and adopting the latest best practices globally in cooperative movement, and for global representation and decision-making which enables the bank to take part in the global decision-making process regarding the strategy of the international cooperative movement. Additionally, the bank has also joined International Cooperative Banking Association (ICBA), an association representing cooperative financial institutions and cooperative banks, affiliated to the ICA (Cooperative Bank of Oromia, 2020; Mahendran et al., 2020).

\section{The Status and Role of Cooperatives and Cooperative Bank of Oromia (Coopbank) in the Socio- Economic Development of Ethiopia \\ 5.1 The Status and Role of Cooperative Sectors in the Socio-Economy}

Cooperatives play an increasingly important role in economic growth, poverty reduction and democratization, if they are democratically organized and managed. The justification provided by Emana \& Nigussie (2011) presumes that through distributing agricultural inputs, providing improved technologies, and encouraging farmers to produce high value crops, cooperatives in Ethiopia have been creating immense socio-economic benefits to both members and outsiders.

Besides, cooperatives are taking part in the distribution of improved seeds, farm implements (such as water pumps), pesticides and herbicides, modern beehives and other agricultural inputs. Evidence verifies that in the cropping period 2012/13, about 110,578.4 tons of improved seeds of different types were distributed by cooperatives (FCA, 2014a). Moreover, they also involve in distributing both quality and quantity nonagricultural input supplies such as construction materials, and consumable goods and also agricultural products at reasonable prices.

In serving as a market channel, cooperatives are also involved in output marketing and creating market opportunities. In doing so, they are achieving good results in the areas of coffee, sesame, grains, animal products, milk and milk products which they have effectively marketed. With this regard, empirical evidence provided by FCA (2014a) reveals that in the year 2007, seven coffee cooperative unions exported about 6,967 tons of coffee and generated revenue of about 24 million USD. This has elevated the export of coffee to 11,532 tons, which has enabled to generate about 76 million USD in 2013. Similarly, over the period of 2009 to 2013, on average cooperatives supplied about 2.5 million tons of grain; 11.7 million liters of milk; 124,404 live animals; 17,356 quintals of fish; and 21,141 quintals of honey per year to the market and improved members' income.

Even though there are all the potential advantages explained, all members are not equally utilizing the said benefits. Farmers in developing countries face a number of problems in marketing. The first group of constraint is a physical condition such as insufficient means of transportation, bad roads, and small and underdeveloped markets. Lack of storage facilities also prevents the farmers from storing their farm produce until the season when the prices rise. This results in loss of income to the majority of the small scale farmers. In overall situations, farmers in developing countries have very small bargaining power, and are exploited by middle men and private traders (Mohammed, 2015).

The direct and indirect employment opportunities created for many individuals is also the other important economic benefits of cooperatives. Cooperatives are the second largest employer in many African countries and some countries around the world, being surpassed only by the government (Schwettmann (ILO COOP), 1994). This could also be considered as a social benefit. As evidence indicated in FCA (2013), to above 623,950 members and to 181,133 non-members about 12,902 direct employment opportunities were created by cooperatives. This implies in the stated period of time, throughout the country, cooperatives have generated more than 805,053 jobs. Now a days, report from FCA shows the number increased to 1.4 million.

Nevertheless, the role of cooperatives in employment creation has been neglected by employment planners, cooperative promotion agencies, social partners and donor organizations alike. In this regard, as to the evidence 
indicated by ILO (2000). "In many African countries, cooperatives were considered primarily as tools to execute certain economic or political functions on behalf of the government, not as autonomous, member-based organizations that create and consolidate self-employment."

In addition to the primary cooperatives, cooperative unions have also been engaged in product processing and value addition, thereby economically benefiting their members. A good example in this case includes Liche Hadiya and Lume Adama cooperative unions that have been involved in value addition through processing (FCA, 2014a). This concludes cooperatives have been playing important roles in economic benefits, ensuring a fair share of resources, and reducing income disparity.

The economic benefits of cooperatives discussed earlier have also their share in contributing to social benefits, as the income earned from cooperatives could be invested in children's education and cover health expenses. Furthermore, as service provision being one of the objectives of cooperatives, both primary cooperatives and cooperative unions should spend about 5\% of their profits as investment in social services (EPRDF, 1998, cited in Mojo et.al, 2017). This has also long-term economic benefits to the cooperatives, since it can help to increase the social capital of the community. Some empirical studies also indicate that cooperatives have significantly positive impact in creating social and human capital (Majee \& Hoyt 2010; cited in Mojo et.al, 2017). In spite of their potentials, only a few cooperative unions are currently undertaking such activities of contributing to the social wellbeing.

Even though wider areas where cooperatives touch in the life of Ethiopian people were mentioned, yet the contribution of cooperatives to the national GDP is less than $1 \%$ (it is $0.9 \%$ ). Thus, this needs the cooperation of all including the government to make the sector contribute significant share to the country's GDP.

Contrary to its multi socio-economic benefits mentioned so far, as some studies indicate, cooperatives have been negatively contributing to environmental sustainability in Ethiopia (Mojo, et al., 2015b). The authors stated that the better prices farmers got from cooperatives motivated the farmers to further increase their yields through intensifying production impacting the forestlands and consequently utilizing the natural resource unwisely. As to the recommendations of scholars, cooperatives should be environmentally sustainable as they are economically viable and socially equitable, as long as they are guided by principles of the International Cooperative Alliance. They are also expected to provide financial and material support for environmental protection, soil and water conservation, forest, wildlife, and air protection activities.

\subsection{The Status and Role of Cooperative Bank of Oromia in the Socio-Economic Development}

In addition to correcting market failure, which is the critical bottleneck of cooperatives by availing finance through providing full-fledged banking services, the bank persistently discharges its social responsibilities for a better life within the communities. The bank believes that being socially responsible is behaving ethically and with sensitivity toward social, cultural, economic, and environmental issues. Accordingly, it continued to promote social responsibility through sustainable practices. Thus, it delivered value on every front to its customers, people, and communities in general (Gobena, 2011).

The bank practices diverse methods as corporate entity, to realize its social responsibility, and donation is one of it. In the fiscal year 2019/20 the bank has involved in various social aspects via donations and sponsorships to sectors like public health, education, community development, environmental protection efforts, natural disasters, and other humanitarian endeavors. For instance, the bank has participated in the various social activities like funding medication expense, sponsorship to socio-cultural novels, and funds made to self-help groups participating on community development. Moreover, the bank has contributed to the 'school feeding Programme to support students in government schools in the city which would help students keep in school and cut dropouts.

Likewise, $\mathrm{CBO}$ has participated on community development by cooperating with Oromia Development Association (ODA), which is contributing to sustainable development, concentrating predominantly on the rural community, through construction of basic infrastructure, provision of social services such as education, health, water, preserving and maintaining the ecological balance. In line with this, CBO supported the association on fund raising program having targeted to construct boarding schools (CBO, 2019).

Even during the hardship condition due to the outbreak of COVID-19 pandemic, the bank has dedicated itself in ensuing socio-economic impacts, and made exceptional support to its employees, customers and the community. It has played its role in awareness creations including its employees through various platforms, hygiene materials and facemasks were supplied, transportation services were availed for employees working in the capital city, and repayment waiver on loan principal were made, among others.

Similarly, CBO had also been participated in environmental protection issues by working together with an indigenous non-profit and non-governmental organization such as Association for Development and Biodiversity Conservation, which is working overall the country. The bank also funded the forum organized by this association with the motto of "conservation for a better quality environment through participation!' evolved out on the humanitarian initiatives, dedicated for development, biodiversity, conversation and mitigation of climate 
change. The Bank also participated in supporting humanitarian activities. It thus sponsored 'Nehemiah Autism Center', which is serving autistic children to reach their full potential. It too had financed 'Macedonians Humanitarian Association' that works in supporting elderly people and people with disabilities by providing them with shelter, clothing, food, and other basic services. In general, the bank involves in the development endeavor of the country through several mechanisms. At CBO, therefore, socially responsible approach is at the heart of what it does.

For its clients, besides rearranging loan settlement framework, the bank made a momentous reduction of loan interest, of up to 5 percent, to pass the situation. Likewise, abandonment of three-month loan interest on the sectors that are highly influenced by the outburst of the virus including tourism, hospitality and horticulture, and that of ATM commission and extension commission on were made. On the other hand, the Bank has made numerous customer engagement and marketing events, including establishing exporters' day and recognizing top foreign currency generators (exporters and money transfer agents).

As compared to the fiscal year 2018/2019, the fiscal year 2019/2020 was one of the instability all over the world, with an economic recession resulting from the coronavirus eruption, and continued weakening of global output and investment. The domestic economy, on the other hand, sustained modest growth as the reform and domestic production continued to fold momentum. Even though the economy expanded expressively for eight months of the fiscal year, the momentum moderated in the last four months due to the pandemic. Apart from the pandemic, during the year, the banking industry was severely confronted with liquidity crisis.

Regardless of these challenges, the bank continued to maintain a healthy growth key metrics and enhanced profitability for the year under review. The year also characterizes a major breakthrough for the bank, as it marked its $15^{\text {th }}$ year anniversary. The bank's balance sheet size raised by 25.6 percent during the period from ETB 41.79 billion to ETB 52.49 billion in line with escalation in deposits and loans. The most imperative foundation of its earning assets remained customers' deposit which raised by ETB 9.34 billion or 25.82 percent to ETB 45.51 billion ensuing to instituting and maintaining of the relationships with our clients. During the fiscal year, the bank was able to earn a total foreign currency of USD 363.42 million with export constituting the largest share of 70.8 percent. In fact, export performance of the country has marginally improved during the year with incomes of about 3.03 billion USD, 14 percent or 300 million USD up from the previous fiscal year (CBO, 2020).

Unpaid loans and advances of the bank were increased by 40.3 percent to ETB 34.21 billion in the FY 2019/20 from the 2018/19 end year value of ETB 24.39 billion. The bank made additional expenditure of ETB 16.66 billion mainly to customers in export, domestic trade, service and manufacturing businesses. As for credit quality, the NPL ratio improved once again, dropping to 2.35 percent during the year, keeping below a regulatory standard of 5 percent and our internal plan. In this fiscal year, the bank has made remarkable improvement in earnings. The bank created record revenue of ETB 5.74 billion, up by 54.6 percent or ETB 2.03 billion from the preceding year's ETB 3.71 billion. Interest income held the main portion of the income with 72.4 percent of the total revenue illustrating sustainability to yield sound benefit to the bank.

In contrast, the total operating expense were ETB 4.32 billion, growing by 46.6 percent from the prior year's balance of ETB 2.95 billion. Interest expenses paid on customers' deposit and personnel expenses together held a substantial share of 61 percent from the expenses.

The bank's consistent growth of earning assets, together with its unrelenting emphasis on efficiency and optimization, enabled the bank to deliver a fundamental profit. The gross profit before tax was hence ETB 1.42 billion, with growth of 85.5 percent from the previous year's balance of 767.01 million. Consequently, the Bank's earnings per share (EPS) for the year became $47 \%$, up from the preceding fiscal year's $36 \%$. The amazing operating profit performance of the Bank during the period was due to effective revenue and expense management practices.

Deposit acts as a main source to offer loans to customers and remains an important factor for the progression of the Bank. This is the main reason for banks' persistent attempt to mobilize deposits of diverse types from different sources. Coopbank has wider access to merchandise deposits through its branch network and depends on that steady funding source as the principal source of funds for lending. In fact, customer deposit is the single largest source of funding for the Bank and accounted for 86.70 percent of the total assets as at June 30, 2020, compared to 86.55 percent, nearly equivalent to a year ago. Deposits of the Bank increased by 25.82 percent during the year and stretched ETB 45.51 billion as of June 30, 2020, compared to ETB 36.17 billion as at the end of the prior year (CBO, 2020).

Deposits from retail branch banking networks constitute a considerable portion of the incremental deposit mobilized during the fiscal year. Structure wise, savings deposit added by 24.2 percent to ETB 28.51 billion, demand deposits grew by 13.4 percent to ETB 13.29 billion, and fixed time deposit raised to ETB 3.19 billion. Structure wise, savings deposit grew by 24.2 percent to ETB 28.51 billion, demand deposits grew by $13.4 \%$ to ETB 13.29 billion and fixed time deposit matured to ETB 3.19 billion.

International trade is also one of the crucial areas where the bank had made outstanding efforts and attained 
modest evolvement during the period. Nevertheless the year was described with very tough challenges; the bank had managed to improve its foreign currency generation, mostly from export earnings. But transfer performance weakened during the period mainly due to the covid-19 pandemic impacts. During the fiscal year, the bank has generated USD 363.42 million, up by 17.1 percent related to the volume generated at the end of June 2019 . In reference to the foreign currency inflow structure of the bank, a significant portion of it is from export earnings with 70.8 percent, up by 26.57 percent from the previous year. The total generated from the private transfer (remittance and SWIFT) constituted 22.28 percent, decreasing by 7.76 percent from the latter year.

With regard to loans and advances, in this fiscal year, the bank had dispersed a significant volume of loans to the bank's customer segments engaged in different economic activities. Therefore, the Bank injected fresh loans of ETB 16.7 billion to various sectors of the economy, increasing its outstanding loan portfolio to ETB 34.21 billion at the year-end, up by 40.3 percent from June 2019. Loans to customers accounted for 64.6 percent, about two-thirds, of the total assets highlighting the significance of maintaining the growth of earning assets to safeguard the profitability of the Bank. When we look at the outstanding loan portfolio by economic sector, international trade took the biggest share of 31 percent, followed by domestic trade and manufacturing with 29.6 percent and 20.6 percent, in their order, at the end of the fiscal year (CBO, 2020).

Branch expansion is also one of the parameter to determine the status of the bank together with service quality improvement. In this regard, in the fiscal year 2019/20, 31 new branches were opened and reached its total branch to 420 . As a result of the addition of these new branches, $6 \%$ of deposits mobilized to the bank in the fiscal year. The bank also created many direct and indirect employment opportunities to the citizens. Among this, direct employment opportunity is created to more than 8.163 .

Since expansion of technology is one of the critical focus areas for supporting business of the bank, it has continued to invest in the area to make things easier in its internal business processes and has registered a notable milestone in laying the groundwork for executing a new digital banking ecosystem. Hence, it continued to undertake IT investments that could respond to the business requirements of the Bank. During the fiscal year, considerable accomplishments were registered in implementing the COOPay-Ebirr digital ecosystem and data center renovation projects. Likewise, various initiatives have been undertaken by the bank to increase its accessibility via alternate channels. Accordingly, the bank deployed an additional 25 new ATM machines, which increased the total ATMs of the bank to 109 as of June 30, 2020 (Mahendran et al., 2020).

In spite of great economic and social instability in all the business around the globe due to the spread of COVID19, the bank granted a donation of ETB 5 million to the National Resources Mobilization Committee and ETB 3 million for Oromia Regional steering committee to fight the potential spread of the virus.

In summary, Cooperative banks play an imperative function in the economy of the country. They are the main intermediaries between those with excess money and those individuals and businesses with viable projects. Of all its endeavors, Cooperative Banks in general and Cooperative Bank of Oromia in particular have at least the following functions: lending money, depositing money, transferring money locally or globally and working as paying agent. Regardless of short period of its emergence, Cooperative Bank of Oromia is contributing considerable share in the Ethiopian economy. From all the activities performed by the bank, its members are benefiting economically, socially and ethically at large. The bank is diversifying its activities other than meeting only consumption credit requirements of its members. It is helping small traders, small businesses, and retail traders, house construction, car or vehicle purchase etc. In doing so, the bank is widely contributing in creating social and economic stability in the country in general and in Oromia region in particular.

\section{References}

Abate, G. T., Francesconi, G. N., \& Getnet, K. (2014). Impact of Agricultural Cooperatives on Small holders' Technical Efficiency: Empirical Evidence from Ethiopia. Annals of Public and Cooperative Economics, 85(2), 257-286.

Addissie Shiferaw \& Dagnachew Asrat (2009). Law of Public Enterprises and Cooperatives: Justice and Legal System: Research Institute, Addis Ababa, pp. 1-197.

Adugna, H. (2013). Co-operative Approach to Community Livelihood Improvement: The Case of Ada'a District, Oromia Regional State, Ethiopia: International Journal of Development and Sustainability, Vol. 2, No. 3 (2013), pp. 2124-2145.

Alemayehu, G., (2001). The structure and performance of Ethiopian's financial sector in the present and post Reform period: with special focus on banking. Work paper.

Bezabih Emana (2009). Cooperative: a Path to Economic and Social Empowerment in Ethiopia: ILO, Coop AFRICA, Working Paper No.9,pp. 9-14,Dare Salam.

Cemal Karakas (2019).Cooperatives: Characteristics, Activities, Status, and Challenges: European Parliamentary Research Service (EPRS).

Cooperative Bank of Oromia (CoopBank of Oromia) (2013). Annual Report, Addis Ababa.

Cooperative Bank of Oromia (CoopBank of Oromia) (2019). Annual Report, Addis Ababa. 
Cooperative Bank of Oromia (CoopBank of Oromia) (2020). Annual Report, Addis Ababa.

Desalegn Fekadu (2019). The Role of Multi-Purpose Cooperatives in the Economic Development in Ethiopia, the Case of Lalo-Assabi District (West Wollega Zone, Oromia Regional State). Research on Humanities and Social Sciences. Vol.9, No.21, pp 13-30.

Emana, B. \& M. Nigussie (2011). Strategizing Cooperative Development in Ethiopia: an unpublished Report Submitted to Agricultural Transformation Agency (ATA). Addis Ababa, Ethiopia.

FCA, (2012). Cooperative Movement in Ethiopia, a Paper Presented at Workshop on Perspectives for Cooperatives in Eastern Africa, Uganda: Kampala. (2014a). Cooperatives. Annual publication 1(11), Addis Ababa: FCA.

(2014b).Unpublished data, Addis Ababa, Ethiopia. (2014). Federal cooperatives Agency, Annual Publication, Vol1, No11

Gary, B. Hansen (ILO COOP) (1993).The role of cooperatives in the promotion of employment and income: Presentation to the Meeting of Experts on Cooperatives, ILO in Geneva Switzerland, No. 3 (1993), pp.8-16, retrieved from: https://aas.org.

Gobena, M. G. (2011). Master of Business Administration (MBA) (Doctoral Dissertation, Andhra University.

Holmberg, Susan Ruth (2011). Solving the Coffee Paradox": Understanding Ethiopia's Coffee Cooperatives through Elinor Ostrom's Theory of the Commons. Open Access Dissertation, PhD. 379.

International Cooperative Alliance (ICA) and International Labor Organization (ILO) (2014). "Cooperatives and the Sustainable Development Goals: A Contribution to Post 2015 Development Debate." A Policy Brief, Geneva.

ICA (2019, July 6). Coops for Decent Work: International Day of Cooperatives Theme. A Policy Brief, Geneva, retrieved from: www.ica.coop.

Kenichi Ohno (2009).Ethiopia: Political Regime and Development Policies, Graduate Institute for Policy Studies (GRIPS), Tokyo.

Kifle Tesfamariam (2015a). Cooperative Movement in Ethiopia: Development, Challenges and Proposed Intervention: Journal of Economics and Sustainable Development, Vol.6, No.5 (2015), pp. 38-45, retrieved from www.iiste.org, ISSN 2222-1700.

Kodama, Y. (2007). New Role of Cooperatives in Ethiopia: The Case of Ethiopian Coffee Farmers Cooperatives, African Study Monographs: Institute of Developing Economies, JETRO, Suppl.35: pp. 87-108.

McCarthy (2001). The History of Agricultural Cooperatives" in Cooperative Business Today. First Quarter Vol.1, Issue 1 (2001), VOCA- Addis Ababa, Ethiopia.

Mohammed N, Lee BW (2015). Role of Cooperatives in Rural Development, the case of South Nations Nationalities and People Region, Ethiopia. Science Journal of Business and Management 3(4):102-108.

Mojo, D., C. Fischer, T. Degefa (2015b). "Social and Environmental Impacts of Agricultural Cooperatives: Evidence from Ethiopia": International Journal of Sustainable Development and World Ecology, 22(5): pp. 388-400.

Mojo, D., C. Fischer, T. Degefa (2017). The Development of Agricultural Cooperatives in Ethiopia: History and a Framework for Future Trajectory: Research Gate, EJOSSAH Vol. XIII, No.1, pp.50-77, DOI: 10.4314/ejossah.v13i1.3, retrieved from: https://www.researchgate.net/publication/322202824.

Nakkiran, S. (2002). A Treatise on Cooperative Management, Head PG Department of Cooperation TBML College, Fourth edition: Rainbow publications, India-Delhi, pp. 1- 593.

Ruhul AM, Mohammed UM (2014). Socio-Economic Impacts of Cooperative Societies: An Empirical Study. SOCRATES: An International, Multi-lingual, Multi-disciplinary, Refereed (peer reviewed). Indexed Scholarly Journal 2(2):179-193.

Schwettmann (ILO COOP) (1994). Cooperatives and Employment in Africa: Final Report of the Regional Advisor on Cooperatives for Eastern, Southern and Central Africa (October 1988 to March 1994): ILO Cooperative Branch: Occasional Discussion Paper 97-1, Geneva.

Tesfay, A. W. (2016). A comprehensive Measure of Business Performance: a Study of the Commercial Banking Industry in Ethiopia (Doctoral Dissertation).

World-Fact book, (2020). Report, s.l.: World Bank.

United Nations Framework Convention on Climate Change (UNFCCC) (2014, January 23). An Integrated Environmental Treaty, Retrieved from: http://unfccc.int/2860.php. 